
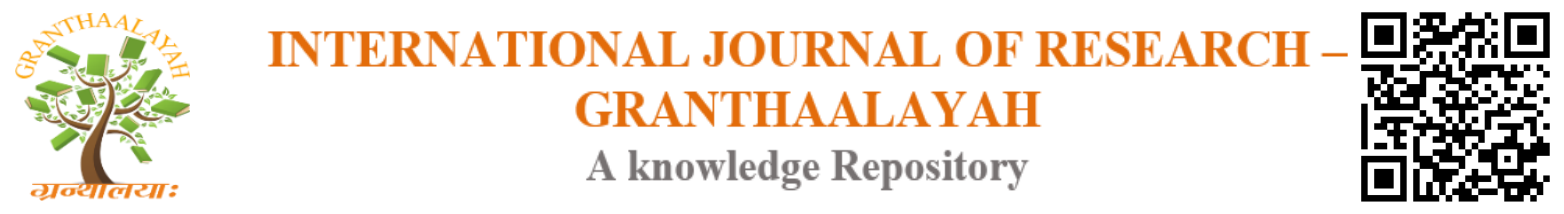

Science

\title{
A PREPARATION AND PHARMACEUTICAL STANDARDISATION OF SURANADI KHAND (GRANULE) - A MODIFIED FORM OF SURANADI
} AVALEHA

\author{
Dr. Sneha Diliprao Lambat ${ }^{1}$, Dr. Mahantesh B. Rudrapuri ${ }^{2}$, Dr. G. Vinay Mohan ${ }^{3}$ \\ ${ }^{1}$ M.D. (Ayu.) Scholar, Department of Post-Graduate Studies in Rasashastra \& Bhaishajya \\ Kalpana, Shri Shivayogeeshwar Rural Ayurvedic Medical College \& Hospital, Inchal,
}

Karnataka, India

${ }^{2}$ Md (Ayu), Professor, Hod Department of Rasashastra and Bhaishajya Kalpana, Shri Shivayogeeshwarrural Ayurvedic Medical College \& Hospital, Inchal, Belgavi, Karnataka, India

${ }^{3}$ M.D. (AYU), Principal Shri Shivayogeshwar Rural Ayurvedic Medical College Inchal. Tal- Saundatti Dist- Belagavi, India

\begin{abstract}
Ayurveda is a science of life. It is mainly based on the Trisutra, Hetu, Linga and Aushadhi. Among these Aushadhi plays a major role in the treatment. The standardization of herbal formulations and neutraceuticals, a thoughtful knowledge of the important herbs found in India Suranadi Khand (Granules) is a Avaleha preparation \& is explained in Sharangadhar samhita. which is used in the Arsha, Mandaagni, Pleehagulma, Shwas, Kasa, Ashtila. In modern era more importance is given for the feasibility, palatability, minimum dose, easy administration, increased bioavailability and shelf life of a formulation. Hence the present study highlights the Preparation and Pharmaceutical Standardization of Suranadi Khand (Granules)- A Modified Dosage form as Suranadi Avaleha.

Keywords: Suranadi Khanda; Pharmaceutico-Analytical Standardization; Surnadi Avaleha.

Cite This Article: Dr. Sneha Diliprao Lambat, Dr. Mahantesh B. Rudrapuri, and Dr. G. Vinay Mohan. (2019). "A PREPARATION AND PHARMACEUTICAL STANDARDISATION OF SURANADI KHAND (GRANULE) - A MODIFIED FORM OF SURANADI AVALEHA.” International Journal of Research - Granthaalayah, 7(8), 463-469. https://doi.org/10.29121/granthaalayah.v7.i8.2019.700.
\end{abstract}

\section{Introduction}

Bhaishajya is the one among Chikitsa Chatuspada, without which the suppression of disease is not possible. Bhaishajya is the weapon offered by Ayurved to conquer the overspreading deadly diseases. ${ }^{(1)}$ Acharya Charak has mentioned Panchavidhakashay Kalpana i.e. swarasa, kalka, $k w a t h$, hima, fant ${ }^{(2)}$ In the same sequence Acharya have mentioned different formulations with the same herbs according to their efficacy, dose and palatability etc. But there are some demerits of these formulations too e.g. large amount of dose, less shelf life etc. 
In today's era more importance is given for the feasibility, palatability, minimum dose, easy administration, increased bioavailability and shelf life of a formulation. Avaleha or Leha is a semisolid preparation of drugs, prepared with addition of jaggary, sugar, and boiled with prescribed drug juice or decoction. ${ }^{(3)}$ The definition of awaleha is "kwathadina punh: pakat kathyate sa rasakriya so avlehach" is mentioned in the sharangdhara samhita madhyam khanda. Suranadi Avaleha kalpna is explained in text of Sharangdhar Samhita, ${ }^{(4)}$ Ashtang Hridayam. ${ }^{(5)}$ Which is indicated for enhancement of Arsha, Mandaagni, Pleehagulma, Shwas, Kasa, Ashtila. Suranadi Avaleha will be prepared by using the ingredients Suran, Dhanyaka, Pippali, Twak, Ela, Patra, Marica, Sunthi, Khanda, Go-ghrita, Madhu.

There is number of classical formulations available for protective as well curative purpose of disease such as Arsha, Mandagni. As per the need of time we have to modified the Suranadi Avleha to suitable forms, Converting it to granules form will ensure its palpability, ease of handling and comfortable for use. No studies have been carried out on this drug yet. Hence the present study planned to evaluate 'Preparation and Pharmaceutical Standardization of Suranadi Khand (Granules)- A Modified Dosage form as Suranadi Avaleha'

\section{Materials and Methods}

\section{Materials}

Table 1: Contains of Suranadi Awaleha and their Properties

\begin{tabular}{|c|c|c|c|c|c|}
\hline No & Dravya & Rasa & Virya & Vipak & Guna \\
\hline 1 & Suran $^{(6)}$ & Katu, Kashaya & Ushna & Katu & Laghu, Ruksha Vishada \\
\hline 2 & Go-ghrita & Madhura & Sheet & Madhura & Singdha, Mrudu \\
\hline 3 & Sharkara & Madhura & Sheet & Madhura & Guru, Snigdha \\
\hline 4 & Pippali $^{(7)}$ & Katu & Ushna & Katu & Laghu, Snigdha \\
\hline 5 & Sunthi $i^{(8)}$ & Katu & Ushna & Madhura & Laghu, Snigdha \\
\hline 6 & Jiraka $^{(9)}$ & Katu & Ushna & Katu & Laghu, Tikshna \\
\hline 7 & Dhanyaka ${ }^{(10)}$ & Kashaya, Katu Tikta & Ushna & Madhura & Laghu, Snigdha \\
\hline 8 & Tejapatra $(11)$ & Katu & Ushna & Katu & Tiksna, Laghu \\
\hline 9 & $E^{(12)}$ & Katu, Madhura & Sheet & Katu & Laghu, Ruksha \\
\hline 10 & Maricha $^{(13)}$ & Katu & Ushna & Katu & Laghu, Tikshna \\
\hline 11 & $T w a k^{(14)}$ & Katu, Tikta & Ushna & Katu & Laghu, Ruksha, Tiksna \\
\hline 12 & Madhu & Madhura,Kashaya & Sita, & Katu & Laghu, Yogavahi \\
\hline
\end{tabular}

Table 2: shows drawys scientific name,part used and quantity

\begin{tabular}{|l|l|l|l|}
\hline Dravya & Scientific Name & Part used & quantity \\
\hline Suran & Amorphophallus campanulatus (Roxb) & Fruit & 100 pal \\
\hline Goghrut & Butyrumdepartum & & 8 pala \\
\hline Sharkara & Sugar & & 400 pala \\
\hline Pippali & Piper longum Linn & Seed & 2 pala \\
\hline Sunthi & Zingiber officinale & Rhizome & 2 pala \\
\hline Jirak & Cuminum cyminum Linn & Fruit & 2 pal \\
\hline Dhanyaka & Coriander sativa & Fruit & Half pal \\
\hline
\end{tabular}




\begin{tabular}{|l|l|l|l|}
\hline Tejpatra & Cinnamommtama & Leaf & Half pal \\
\hline Ela & Elettaria cardamoummaton & Seed & Half pal \\
\hline Maricha & Piper nigrum Linn & Fruit & Half pal \\
\hline Twak & Cinnamomum zeylanicumblume & Bark & Half pal \\
\hline Madhu & Honey & & Qua. Req \\
\hline
\end{tabular}

\section{Methods}

1) Avaleha Preparation (15)

- Fresh Surana and other ingredients was collected and cleaned

- (To remove foreign matter)

- Kept in clean steel vessel

- Surana was peeled, Cut into small piece

- Distilled water in quantity double to Surana and was heated on Mandagni

- When Surana pieces becomes soft, were mashed to paste

- Paste was fired in ghee on Mandagni till it turned to brown

- Sugar four times quantity to that of paste were added in the water and boiled till paka attains Aapsumajjati, Tantumatwa

- Fried paste were added to the paka

- It will be mixed vigorously\& stirred continuously till the Avaleha attends Siddha Lakshan.

- When it becomes Swanga shita, honey will be added in requierd quantity to prepared suran avaleha

\section{2) Granules Preparation}

- Prepared Avaleha was taken

- When it becomes Swangasita, add prakshep dravya and honey was added in required quantity and stirred again to prepared Suran Khanda (Granule)

\section{Pharmaceutical Study of Suranadi Khand}

Suranadi Khand (Granules) is a Avaleha preparation \& is explained in Sharangadhar samhita. This was prepared by using drugs like Surana, Ghrita, Sharkara, Pippali, Sunti Dhanyak, Twak, Jeerak \& Madhu. The drugs were taken in appropriate quantity as shown in the Table no 2. Mandagni (mild fire) was applied to perform Avaleha preparation. Kalpa Siddhi Pareeksha were observed clearly. The temperature recorded at this stage was $65-70^{\circ} \mathrm{c}$. then after cooling honey was added to the mixture $\&$ mixed uniformely. The temparaure recorded at this stage was $35^{\circ} \mathrm{c}$. after uniform mixing the whole mixure was converted in to homogeneous blende. This blende was taken for Granule preparation with help of mesh no 40\#. Suranadi khand granules were prepared in 3 sample $\&$ were analyzed separately. Physico chemical parameters of the individual drugs (Table no 5) and Suranad khand granules (Table no 6) were suggestive of the quality and increased shelf life.

\section{Physico-Chemical Study of 3 Samples of Suranadi Khand Granules:}

\section{Organoleptic Characteristics}

Organoleptic properties are mentioned in the table no 6. The developed formulation was Light yellow colored, characteristic odor, semisolid in consistency in the samples of SK granules $1 \& 2$. 
But In the sample SK granules 3 had light yellowish in color. The remaining observations were similar to sample $1 \& 2$.

\section{Loss on Drying}

Moisture content of sample Suranadi Khand Granules 1,2,3 was found 1.39\%, 1.39\%, S\& 1.37\% respectively (Table no 6). It indicates moisture content. Low moisture content is desirable for higher stability of the formulation.

\section{Ash Value}

Ash value of sample Suranadi Khand Granules 1,2,3 was found $2.97 \%, 2.37 \%$ \& $2.35 \%$ respectively (Table no 6). This value was found to be reasonably low, which indicates low contamination. It is criteria for indentifying the purity of the drugs. Total ash is inclusive of extraneous matter such as sand, soil etc adhering to the herbal drug.

\section{Water Soluble Ash}

Water soluble Ash of sample Suranadi Khand Granules 1,2,3 was found 0.59\%, $0.57 \%$ $0.55 \%$ (Table no 6) respectively. This shows normal quality of the drugs of the Suranadi Khand (Granules 1,2,3) and presence of more active principle in the sample.

\section{Acid Insoluble Ash}

Acid insoluble ash of sample Suranadi Khand Granules 1,2,3 was found 0.53\%, $0.63 \% 0.53 \%$ respectively (Table no 6). This shows indicative of very less amount of non-physiological components like silica, less adherent dirt and sand particles of the Suranadi Khand Granules.

\section{The Water-Soluble Extractive}

sample of Suranadi Khand Granules 1,2,3 were found to be $67.15 \%, 67.13 \%, 67.09 \%$ respectively and

\section{Alcohol Soluble Extractive}

sample of Suranadi Khand Granules 1,2,3 were found to be 53.37\%, 53.39\%, 53.49\% respectively, indicating considerable amount of polar compounds in the sample.

\section{Ph Value}

$\mathrm{pH}$ of Suranna khand Granules $(1,2,3)$ was 6 , which is a weak basic. This indicates granules is gastric friendly, does not cause harm to the gastric mucosa and maintains integrity of gastric mucosa.

This has shown acidic nature of formulation, due to the reason of use of hanoey $\&$ other ingradients in Paak process.

Total Sugar of Suranna khand Granules $(1,2,3)$ was found to be in the range of $41.68 \%, 41.68$ $\%, 414.66 \%$ (Table no 7) respectively, suggested that considerable amount of Sugar in the sample, as well exhibits solubility of the manufactured product and nutritional value in terms of carbohydrate.

Reducing Sugar of Suranna khand Granules $(1,2,3)$ was present respectively (Table no 7$)^{50}$. 
Total Solid Content of Suranna khand Granules (1,2,3) was found 0.26 gm (table no 7), which in turn shows low moisture content, important factor for longer stability period.

The total fat of Suranna khand Granules $(1,2,3) \quad$ was found to be $0.21 \mathrm{gm}, 0.21 \mathrm{gm}, 0.20 \mathrm{gm}$ (Table no 7) respectively. As SK granules is also used for giving energy, it is expected to be high in Calorific Value.

Total Acidity was found to be $0.12 \%, 0.12 \%, 0.13 \%$ (Table no67) shows within the limit.

TLC (Table no 5) reveals the presence of presence of Phyto constituents in the individual ingredients.

HPTLC study was performed to get finer results (Table no 6) to get finer details. Analysis of the data obtained from the analytical study suggests that the parameters will be useful for standardization of Suranadi khand Granules.

\section{Results}

The results were assessed in following sections. Granular form of Suranadi Khand was subjected to Physico chemical analysis. The results are tabulated in following tables.

Table 5: Physico chemical analysis of raw drugs

Test Parameters

Results obtained in \%

\begin{tabular}{|l|l|l|l|l|l|l|l|l|l|} 
Ingredients & Color & \multicolumn{1}{|c|}{ Odor } & $\begin{array}{c}\text { Moisture } \\
\text { content }\end{array}$ & $\begin{array}{c}\text { Total } \\
\text { Ash }\end{array}$ & $\begin{array}{c}\text { Water } \\
\text { soluble } \\
\text { ash }\end{array}$ & $\begin{array}{c}\text { Acid } \\
\text { in } \\
\text { soluble } \\
\text { ash }\end{array}$ & $\begin{array}{c}\text { Water } \\
\text { soluble } \\
\text { extract } \\
\text { ives }\end{array}$ & $\begin{array}{c}\text { Alcohol } \\
\text { Soluble } \\
\text { Extractives }\end{array}$ & TLC \\
\hline Sharkara & White & $\begin{array}{l}\text { Charactes } \\
\text { tics }\end{array}$ & $2.65 \%$ & $\begin{array}{l}2.02 \\
\%\end{array}$ & $\begin{array}{l}1.37 \\
\%\end{array}$ & 0.19 & 39.10 & 34.06 & 0.11 \\
\hline Pippali & black & aromatic & 2.01 & 2.74 & 1.94 & 0.51 & 28.83 & 31.29 & 0.69 \\
\hline Sunti & $\begin{array}{l}\text { Light } \\
\text { yellow }\end{array}$ & aromatic & 3.37 & 3.12 & 1.96 & 0.81 & 39.94 & 41.83 & 0.02 \\
\hline Jeerak & $\begin{array}{l}\text { Light } \\
\text { brown }\end{array}$ & aromatic & 1.02 & 2.72 & 1.97 & 0.12 & 43.60 & 39.12 & 0.49 \\
\hline Dhanyak & $\begin{array}{l}\text { Light } \\
\text { yellow }\end{array}$ & Aromatic & 1.39 & 2.09 & 1.65 & 0.28 & 53.75 & 61.63 & 0.53 \\
\hline Tejapatra & Greenish & Aromatic & 1.48 & 1.20 & 0.99 & 0.12 & 39.26 & 47.17 & 0.11 \\
\hline Ela & greenish & aromatic & 2.83 & 4.91 & 1.45 & 0.12 & 28.93 & 37.18 & 0.35 \\
\hline Mareech & black & aromatic & 1.37 & 3.18 & 2.95 & 0.51 & 28.45 & 32.90 & 0.55 \\
\hline Twak & $\begin{array}{l}\text { Light } \\
\text { brown }\end{array}$ & Aromatic & 1.48 & 3.37 & 2.01 & 0.5 & 42.84 & 36.93 & 0.17 \\
\hline
\end{tabular}


3 samples of Suranadi Khand Granules was subjected to Physico chemical analysis. The results are tabulated in following tables.

Table 6: Physio chemical analysis of 3 sample of Suranadi Khand Granules

\begin{tabular}{|l|l|l|l|l|}
\hline \multirow{2}{*}{ Sr No } & Test Parameter & SK Granules 1 & \multicolumn{1}{c|}{ SK Granules 2 } & SK Granules 3 \\
\hline $\mathbf{1}$ & Color & Light Yellow & Light Yellow & Light Yellowish \\
\hline $\mathbf{2}$ & Odor & Characteristics & Characteristics & Characteristics \\
\hline $\mathbf{3}$ & Loss on drying at 105oc & $1.39 \%$ & $1.39 \%$ & $1.37 \%$ \\
\hline $\mathbf{4}$ & Ash value & $2.97 \%$ & $2.37 \%$ & $2.35 \%$ \\
\hline $\mathbf{5}$ & Water soluble ash & $0.59 \%$ & $0.57 \%$ & $0.55 \%$ \\
\hline $\mathbf{6}$ & Acid insoluble ash & $0.53 \%$ & $0.63 \%$ & $0.53 \%$ \\
\hline $\mathbf{7}$ & Water soluble extractives & $67.15 \%$ & $67.13 \%$ & $67.09 \%$ \\
\hline $\mathbf{8}$ & Alcohol-Soluble Extractives & $53.37 \%$ & $53.39 \%$ & $53.49 \%$ \\
\hline $\mathbf{9}$ & pH & 6 & 6 & 6 \\
\hline $\mathbf{1 0}$ & Total Acidity & 0.12 & 0.12 & $0.13 \%$ \\
\hline $\mathbf{1 1}$ & HPTLC & 0.19 & 0.19 & 0.19 \\
\hline
\end{tabular}

\section{Discussion}

Preparation \& Pharmaceutical Standardization of Suranadi Khand (Granules)- A modified dosage form of Suranadi Avaleha was taken in this study. Samples selected for the study shows that analytical standards were in accordance with API standards.

Physico chemical parameters of the individual drugs and Suranadi Khand (Granules) were suggestive of the quality and increased shelf life. Parameters results of Powered drugs were as per the guidelines of Ayurvedic pharmacopoeia of India.

\section{Conclusion}

The analytical parameters were within the parameters mentioned in the API and were suggestive of the genuine of the raw material used and the quality of the end product obtained. The data obtained from Analytical parameters of Suranadi Khand (Granules) can be considered as reference for its standardization.

The Physico chemical parameters such as loss on drying, Total Ash value, water soluble ash, acid insoluble ash, $\mathrm{pH}$, Alcohol soluble extractives, Water soluble extracives, , Acid insoluble ash, Water soluble a sh, TLC, Total Acidity, Total Solid Content, Fat Content, Reducing Sugar, Total Sugar, HPTLC and Organoleptic characteristics can be efficiently used for standardization of Suranadi Khand Granules.

\section{References}

[1] Dr. Brahmanada Tripathi, Charak Samhita of Maharshicharak, Vol. ${ }^{\text {st }}$ Chukhambha prakashan, Varanasi, 2011, Sutrastan, chapter 1, verse no.134, page no.48 
[2] Dr. Brahmanada Tripathi, Charak Samhita of Maharshicharak, Vol.1 ${ }^{\text {st }}$ Chukhambha prakashan, Varanasi, 2011, Sutrastan, chapter 4, verse no.6, page no.69

[3] Dwarakaprasad Mishra (Shastri), Sharangdhara Samhita of Acharya Sharangdhar (Madhyam Khanda, 8/1) with the commentary published by Choukhamba Sanskrit Series Office, Varanasi, First Edition 2010 Page no. 210.

[4] Dwarakaprasad Mishra (Shastri), Sharangdhara Samhita of Acharya Sharangdhar (Madhyam Khanda, 8/29) with the commentary published by Choukhamba Sanskrit Series Office, Varanasi, First Edition 2010 Pg no.212.

[5] Dr. Tripathi, Ashatang Hrudaya, Chukhambha Sanskrit prakashan,.

[6] Varanasi, 2010 Chapter no. 8 verse no. 156.

[7] The Ayurvedic Pharmacopoeia of India (API), Ayush \& Family welfare dept. GOI, Vol. $3^{\text {rd }}$, Reprint 2009. Page no.206

[8] The Ayurvedic Pharmacopoeia of India (API), Ayush \& Family welfare dept. GOI, Vol.4 ${ }^{\text {th }}$, Reprint 2009. Page no. 105

[9] The Ayurvedic Pharmacopoeia of India (API), Ayush \& Family welfare dept. GOI, Vol.1 ${ }^{\text {st }}$, Reprint 2009. Page no. 138

[10] Dr. Deshpande A.P., Dravyagunvidnyanium, proficient publishing house.reprint 2015 page no.614

[11] Dr. Deshpande A.P., Dravyagunvidnyanium, proficient publishing house.reprint 2015 page no.605

[12] The Ayurvedic Pharmacopoeia of India (API), Ayush \& Family welfare dept. GOI, Vol.4 $4^{\text {th }}$, Reprint 2009. Page no. 141

[13] Dr. Deshpande A.P., Dravyagunvidnyanium, proficient publishing house.reprint 2015 page no.799

[14] The Ayurvedic Pharmacopoeia of India (API), Ayush \& Family welfare dept. GOI, Vol. $3^{\text {rd }}$, Reprint 2009. Page no. 155

[15] The Ayurvedic Pharmacopoeia of India (API), Ayush \& Family welfare dept. GOI, Vol. ${ }^{\text {st }}$, Reprint 2009. Page no. 151

[16] Sharangdhara Samhita of Acharya Sharangdhar (Madhyam Khanda, 8/22-28) with the commentary Pandit Dwarakaprasad Mishra (Shastri), published by Choukhamba Sanskrit Series Office, Varanasi, First Edition 2010

\footnotetext{
*Corresponding author.

E-mail address: snehalambati1991@gmail.com/mbrudrapuri@gmail.com/vinaymohang@gmail.com
} 